\title{
Financial Distress and the Business Cycle
}

\author{
J avier Suarez \\ CEMFI and CEPR \\ Oren Sussmany \\ Ben-Gurion University and MCER
}

October 1999

\section{Introduction}

In spite of many important dixerences, Keynesian and 'real' business-cycle theories (i.e., most of modern macroeconomics) have one feature in common. They view the business-cycle as a propagated response to a 'shock' that hits the economy from the outside. Confronted with this uniformity of opinion, it is somewhat surprising to discover that some of the greatest thinkers of the past held remarkably dixerent views on the matter.

Bagehot (1873), in a chapter called "W hy Lombard Street is Often Very Dull, and Sometimes Extremely Excited," draws the distinction between two sorts of 'panics'. Some are caused by a "sudden event which creates a great demand for actual cash." Others cannot be attributed to "irregular external accidents, but likewise to regular internal change." It is the "recurrence of these periodical seasons of delicacy which has given rise to the notion that panics come according to a ..xed rule, [and] that every ten years or so we must have one of them."

After noting that "common books of political economy" tend to ignore the phenomenon, Bagehot develops his own theory of 'endogenous' cycles. It

\footnotetext{
${ }^{x}$ We thank Colin Mayer, Alan Morrison, and J ean-Charles Rochet for their helpful comments and suggestions.

' W hile writing this paper Sussman was a visting TMR fellow at the London Business School, Contract No. FRMX-CT 960054.
} 
starts when a "surplus of loanable capital which lies in the hands of bankers [but] is not employed by them in any original way" is lent out, creates an expansion of real activity, and raises interest rates and commodity prices. This expansion ends when, "at the last instant of prosperity, the whole structure is delicate." T wo factors stand behind this delicacy. The ..rst is "great mistakes" committed during the period of rising prices as traders "altogether over-estimated the demand for the article they deal in." The second is that the good times of "high prices almost always engender much fraud." Interestingly, the whole phenomenon is related to the emergence of modern ..nancial capitalism and the incidence of intermediation; it was hardly visible before the end of the $17^{\text {th }}$ century.

Schumpeter's (1996) theory of cycles is quite similar to that of Bagehot's. He also believed that the most important source of cyclicality is internal, as a boom "creates out of itself an objective situation [which] leads easily to a crisis, necessarily to a depression" (italics at source, p. 236). The special feature of Schumpeter's theory is that business cycles and economic development are interrelated via entrepreneurial innovation and decay. ${ }^{1}$ "P ro..ts in a boom [and] losses in depression... are essential elements of the mechanism of economic development... [and] the complete destruction of those existences which are irretrievably associated with the hopelessly unadapted" (p. 253). (Schumpeter was thus sceptical of anti-cyclical policy.) He was therefore interested in analysing the dixerential exect of a recession on old and new business. "An old business has the buxer quasi-rent... It is embedded in protecting relationships, often exectively supported by banking connections of many years' standing... Therefore, it holds out much longer than a new enterprise, which is strictly and suspiciously scrutinised... and which only needs to give a sign of embarrassment to be considered as a bad debtor" ( $p$. 241).

Likewise, Fisher (1933) starts his famous paper with the distinction between factors "imposed on the economic mechanism from outside... [like] sun spots or transits of Venus" and those that are "self-generating, operating analogously to a pendulum" (p. 338). In most cases, these self generating

\footnotetext{
${ }^{1}$ Hence, "the intensity of development [in A merica] presumably makes the $\ddagger$ uctuations more strongly marked than in Europe."
} 
cycles tend to die out; but not always, like "a ship which, under ordinary conditions is always near a stable equilibrium, but which, after being tipped beyond a certain angle, has no longer this tendency to return to equilibrium" (p. 339). His debt dełation theory has such a mechanism. Following "debt liquidation" and "distress selling," prices fall so that "the more debtors pay the more they owe" (p. 344) leading to a situation similar to the capsizing of a ship.

Such explanations of the business cycle were abandoned in the second half of the $20^{\text {th }}$ century. ${ }^{2}$ It is beyond the scope of the present paper to explain why. However, in Suarez and Sussman $(1997,1999)$ we develop dynamic rational-expectations models that share much in common with the abovecited work of the old masters. ${ }^{3}$ Business cycles are created endogenously, driven by moral-hazard relations between ..rms and their providers of ... nance. The institutional environment in which these relations are formed may axect the intensity of the fuctuations; structural change in ..nancial market will have an exect on the business cycle. In the second of the above papers, ..rm liquidation and ..re sales of assets under ..nancial distress play a central role. Also, the severity of the moral hazard problem changes over the cycle and is intimately tied to market prices. In this paper we explain these results in a non-technical way, elaborate on some of them, demonstrate the validity of some of the empirical predictions, and point out the major policy implications.

We share a common thrust with some other contemporary work. Bernanke, Gertler, and Gilchrist (1998) provide a comprehensive survey of the literature on the ..nancial 'ampli..cation exect'. The idea is that ..nancial frictions amplify the exect of external shocks. In that respect, our work can be interpreted as a demonstration that the ampli..cation exect can be unbounded: even as the magnitude of the shocks tends to zero, economic activity still łuctuates. Morris and Shin (1999) develop 'endogenous uncertainty' models and apply them to bank and creditors' runs. The łuctuations generated by their models are random, unlike ours, which are deterministic. Nevertheless,

\footnotetext{
2Patinkin's (1965) exhaustive survey of the macroeconomic wisdon of the 1960's does not bother to mention any of the above texts.

${ }^{3} T$ he rationality of expectations imply that Bagehot's 'mistakes' play no role in our theory. However, moral hazard plays a simmilar role to 'fraud' in his theory.
} 
both their theory of risk and our theory of cycles emphasize that business instability is endogenously determined. Allen and Gale (1998) develop a model where asset prices may depart from their fundamental value due to moral hazard in ..nancial markets, giving rise to 'bubbles'. Our models may be given a similar interpretation, with the bubbles emerging in the booms and bursting in the busts, deterministically.

The rest of the paper is organized as follows. In Section 2 we give a brief and non-technical description of the model of reference. In Section 3 we discuss its time-series implications. The discussion is split into two subsections: the ..rst deals with the variability across the boom and the bust, while the second uses the model in order to explain some of the 'breaks' actually observed in time-series data. Section 4 discusses the main policy implications of the analysis and Section 5 concludes.

\section{The Model: Brieły}

In Suarez and Sussman (1999), we construct an equilibrium where cycles are driven by defaults and 'distressed' asset sales (i.e., the sale of assets during episodes of ..nancial distress). Our economy goes on for ever, but the ..rms' life-span is of, at most, three 'periods' because both the owner-manager of each ..rm and its equipment do not live longer. Starting up (say) at period $t$, the manager buys equipment at a relative price of $q \mathrm{t}$. If all goes well, the ..rm will be productive for the next two periods. As already implied, depreciation rates are high: the equipment is fully depreciated by $t+2$; while at $t+1$ its second hand price is just a small fraction of the price of new equipment, $q_{t+1}$. Hence, ..rms do their best to avoid early liquidation.

At the equipment prices that prevail in equilibrium, all ..rms are profitable. However, some ..rms will suxer a 'liquidity shock' that axects the timing, but not the discounted value, of their cash $\ddagger$ ow. ${ }^{4}$ The liquidity-short ..rms fail to generate any cash at $t+1$, but capitalize an equivalent amount at the next production period (i.e., $t+2$ ). It follows that in a frictionless world, all ..rms, liquidity-short or not, would beeconomically viable. In such a world

\footnotetext{
${ }^{4}$ Liquidity shocks are random at ..rm level, but the fraction of ..rms hit by the shock every period is ..xed, so the individual shocks do not generate a macroeconomic shock.
} 
..rms would avoid early liquidation and there would be no transactions in the second hand market for equipment. Since the demand for new equipment is stable (at a level that is determined by the new cohorts of owner-managers), the economy will converge, immediately, to a stationary equilibrium.

The case of imperfect ..nancial markets is obviously more interesting. Suppose that owner-managers are born penniless and have to raise funds from some wealthy ..nanciers. Suppose, also, that cash-łow is not 'veri..able' in court. Then, if a liquid manager defaults on his debt arguing that the ..rm did not generate any cash, the ..nancier has no way to prove that he is a liar. That raises an enforcement problem. To resolve it, a prudent ..nancier will retain a legal right to liquidate the ..rm upon default. It turns out that the mere threat of liquidation is suф cient to resolve the enforcement problem, because a liquid ..rm will rather pay its debt than risk early liquidation. This remedy, however, comes with a cost: if the ..rm is illiquid, it has no choice but to default, in which case the ..nancier may still exercise his rights (and pocket the revenue from selling the equipment). Remember, however, that illiquid ..rms are still pro..table from a net-present-value point of view. Hence, liquidation rights are a sort of a necessary evil which is required in order impose discipline on ...rms. ${ }^{5}$

To mitigate this necessary evil, the threat of liquidation should be used with moderation. Financial contracts should control the ease with which the liquidation-right is exercised: suc cient to provide an incentive to repay, but not too harsh, so as to avoid unnecessary liquidations. One can imagine that the liquidation right can be easily exercised when ..nance is supplied under a debt contract, when the lending is collateralized, and when the debenture is concentrated in the hands of a single lender such as a bank. The liquidation right is more dic cult to exercise otherwise. We quantify the likelihood that the ..nancier will succeed in exercising his rights by the variable ${ }^{-}{ }_{t}$. From now on, we say that ..nance is 'tight' if the ..nancier's liquidation rights can be easily exercised (i.e., ' is high), and 'relaxed' otherwise.

Note that ${ }^{-}$is indexed by time and may vary according to market conditions. Indeed, the manager and the ..nancier will be wise to adjust the

\footnotetext{
${ }^{5}$ Our analysis of the contract problem relies on the work of Bolton and Scharfstein (1996) and Hart and Moore(1998).
} 
contract to the price at which the equipment is bought, $q_{t}$, and to the price at which the ..rm is anticipated to be liquidated (in case of default), $q_{t+1}$. The higher is $q_{t}$, the more the ..rm has to borrow when starting up and the more tempting it is to default on the repayments, so ..nance has to be tightened up. The threat of liquidation will have to be reinforced so as to induce the liquid ..rms to pay, but this will come at the cost liquidating more of the liquidity-short ..rms, whose only choice is to default. Conversely, the higher is $\mathrm{q}_{\mathrm{t}+1}$, the more exective is the threat of liquidation, so that ..nance can be supplied under more relaxed conditions. ${ }^{6}$

It turns out that these elements are suф cient to support an endogenous, alternating boom-bust equilibrium. Starting with a boom, $q_{t}$ is high and .nancial contracts are tightened up. That will increase the incidence of distressed asset sales next period, decrease the demand for new equipment and will lead the economy to an output slump and recession, accompanied by depressed equipment prices. ${ }^{7}$ But a lower $q_{t+1}$ will bene..t contemporary start-ups because they will purchase equipment at lower prices and will be able to raise ..nance more comfortably. That means that there will be fewer liquidations and the economy will boom again at $\mathrm{t}+2$ :

Our model's equilibrium cycles are deterministic, perfectly foreseen, and create a pattern that exactly replicates itself over time: one period is a boom, the next is a bust, and so on, with the same levels of output, equipment prices etc. in each boom-bust cycle. ${ }^{8}$ Needless to say, this is not how real-world time series look like. This problem could be ..xed, however, by adding small shocks or by complicating the dynamic structure of the model, aiming at some theory of higher order or 'chaotic' ¥uctuations. For the while, we prefer to focus on a model which is simple, but can generate a rich set of predictions and some interesting policy implications, and highlights what seems to be an important hypothesis: that the business cycle is generated endogenously from ..nancial frictions.

\footnotetext{
${ }^{6}$ Technically, ${ }^{-}{ }_{\mathrm{t}}={ }^{-}\left(\mathrm{q} ; \mathrm{q}_{\mathrm{+}+1}\right)$ with ${ }^{-}{ }_{1}>0$ and ${ }^{-}{ }_{2}<0$ :

${ }^{7} \mathrm{~T}$ he ..rst and second hand markets are linked via the assumption that second hand equipment can be restored to new by a certain investment. A second hand machine is thus equivalent to a fraction of new machine.

${ }^{8}$ In the simulations below we set the calendar duration of each period to ..ve years.
} 


\section{Time-series Implications}

In Suarez and Sussman (1999) we run simulations, substituting in realistic values for the model's parameters. We thereby predict how certain variables (output, equipment prices, etc.) ‡uctuate across the boom and the bust. We also use the model in order to predict how structural changes in ...nancial markets would create 'breaks' in the time series. In this section we survey the empirical literature and argue that the evidence is consistent with the model's predictions.

Admittedly, the empirical evidence in favor of our model is not as abundant as we would have liked, simply because of the relative scarcity of empirical work on second-hand markets and the cyclical patterns of corporate ..nance. Comprehensive time series on the number of ..rms suxering ..nancial distress, the amount of distressed asset sales, the volume of trade in the second hand market, let alone a price index for that market, simply do not exist. We have tried to assemble whatever scattered evidence there exists. The good news, of course, is that there is still land to claim within this area.

\subsection{Variability over the boom and the bust}

Table 1 contains our benchmark simulation (see the Appendix for details about how the numbers are generated). The ..rst two lines just establish what the boom and the bust are in terms of output and investment. The parametrization of the model ensures that the amplitude of output across the boom and the bust, $7.5 \%$, is within a reasonable order of magnitude.

\section{[insert Tabl e 1 about her e]}

One of the main implications of our model is that liquidation rates are higher in the bust than in the boom. The third row in Table 1 provides the (yearly) percentage of ..rms which are liquidated. Note that this variable is a combination of the incidence of liquidity shortages (which is constant over the cycle, by assumption) and ${ }^{-}$, the probability that the ..nancier will exercise his liquidation rights after default (which varies along the cycle according to the tightness of ...nancial contracts). 
Unfortunately, even this simple prediction of our model is hard to verify. Dun $\&$ Bradstreet provide a comprehensive time series on business failures in the US. B etween 1951 and 1978, the yearly failure rate of US ..rms ranged between $0.3 \%$ and $0.7 \%$ (see Altman, 1983), which is way below the numbers in Table 1. Note, however, that these ..gures are just the 'tip of the iceberg,' as distressed sales of assets are way more common than fully-łedged business failures - see Gilson, J ohn and Lang (1990). A more comprehensive measure of ..nancial distress comes from banking data, because banks may report losses even if the business did not formally fail (i.e. was partially liquidated). Figure 1 shows that since the early 1980's the write-oxs of US banks represent around $1 \%$ of their total lending. However, Franks and Torous (1989) report that banks recover about $86 \%$ of their exposure in distressed ..rms, implying that behind every dollar of write-oxs there are several dollars of distressed asset sales. So the numbers reported in Table 1 do not seem that absurdly high. As for the incidence of failure across the boom and the bust, the data in A Itman (1989), Plat and Plat (1994), and our Figure 1 seems in line with our predictions. ${ }^{9}$

[insert Figure 1 about her e]

The next row in Table 1 presents the model's prediction about equipment prices, $q_{t}$. Here, the evidence is somewhat more available. One of the ..rst systematic studies of the second hand market is due to Pulvino (1998). He collected data on all transactions in second-hand narrow-body aircraft that took place in the United States around the early 1980 's. ${ }^{10}$ Running a 'hedonic price' regression, he ..Itered out the aircraft-speci..c components (such as age, model, state of engine, etc.) to construct a comprehensive price index for second-hand transactions. This index shows a strong pro-cyclical pattern: as the industry entered recession in 1981, prices fell sharply. The boom-bust amplitude was between $40 \%$ and $60 \%$ in real terms. Pulvino is also able to identify which transactions had a ..nancially distressed seller. He estimates that such transactions went at a discount of $13 \%$ relative to the market price

\footnotetext{
${ }^{9} \mathrm{~A}$ similar picture comes from work in progress by J ulian Franks and Oren Sussman based on non-listed UK companies in ..nancial distress.

${ }^{10} \mathrm{H}$ is work was motivated by the theoretical predictions of Shleifer and Vishny (1992).
} 
at that point in the cycle, which suggests the existence of a causal relationship from distressed sales to price movements along the cycle.

Some extra evidence is provided by the cyclical behavior of real-estate prices. Higgins and Osler (1997) analyze the recession that swept across the OECD countries in the late 1980's and early 1990's. They report a boomto-bust real-price amplitude in commercial property prices of between $40 \%$ and 60\%. Englund (1999) ..ndings for Sweden are even more dramatic: the price of primelocation real-estate in Stockholm increased 9-folds along an expansion period that lasted ten years, and they halved when the 'bubble' burst.

A nother important implication of our model is that the higher rates of liquidation during the bust are a result of contractual rights obtained during the boom. Having to ..nance investment in highly priced capital goods, and anticipating that these prices will fall in the bust to come, ..nanciers recognize that boom start-ups have a stronger temptation to breach their contract. So they tighten the terms of ..nance and intensify the threat of liquidation in order to ensure performance. ${ }^{11}$ It would have been desirable to ..nd some evidence of this 'tightening up' exect. As noted above, we would expect to ..nd that the ..nancial arrangements started at the boom are better collateralized and have their liquidation rights less dispersed among the ..nanciers so as to allow quick action in case of distress. Unfortunately, we are not aware of any empirical study that throws light on this issue.

Arguably, debt ..nance is better suited than equity for the purposes of imposing an exective threat of liquidation in case of default (especially if banks are not allowed to hold equity). If this is the case, we would expect that the corporate sector becomes more highly levered towards the end of the expansion period. Again, surprisingly little work has been done on that exect. In Figure 2 we plot the evolution of leverage, as measured via the corporate-sector's income $\neq$ ow. The cyclical pattern of the series is clear cut and shows that higher leverage indeed precedes the arrival of recessions. For similar evidence, see Gertler and Lown (1999), Figure 4. ${ }^{12}$

\footnotetext{
${ }^{11} \mathrm{~N}$ ote that in spite of the fact that ..nance is 'tightened' the volume of ..nance expands during the boom because of the higher prices of capital goods.

${ }^{12}$ Credit expansion is quite a common feature of 'bubble' periods. See Mishkin (1996) for some dramatic evidence from M exico.
} 
[insert Figure 2 about her e]

A more straight-forward feature of our model is that ..nanciers foresee the changing price of capital goods along the cycle and adjust the terms of the ..nancial contract accordingly. Consistent with the last row in Table 1, Gertler and Lown (1999) provide evidence of the cyclical behavior of the terms of ..nance. They show that the junk-AAA spreads provide a good leading indicator of output ¥uctuations, anticipating recessions about one and a half years in advance (see their Figure 2). They also ..nd that this relation has strengthened in the period after 1985 . We elaborate on this and similar 'breaks' in some relevant time series in the next sub-section.

\section{2 'B reaks' in the series}

One of the most interesting implications of our model is that structural, legal, regulatory or institutional change in ...nancial markets may alter the pattern of business łuctuations. Indeed, the last thirty years of US history are full of such changes. A quick look at Figures 1 and 2 reveals clear 'breaks' in the time series of leverage and bad debt around the early 1980's; the breaks in both series are likely to be related. Our model suggests a mechanism through which the changes that axect ..nancial structure may alter the patter of the business cycle. In this sub-section we explore this possibility.

We start with a change in corporate bankruptcy law. By and large, bankruptcy law determines the allocation of power between the ..rm and its ..nanciers in case of default. In some countries, like the UK, it tends to concentrate power in the hands of the secured lenders. In others, like the US, the historical trend has consisted in distributing power away from the secured lenders and in favor of the company and its unsecured lenders. A clear step in that direction was the Bankruptcy Reform Act of $1978 .{ }^{13}$ R eforms like this are frequently intended to help businesses to survive during the hard times of recession and distress.

In our model, this structural change has an exect on business łuctuations, for it will axect the incidence of liquidation, equipment prices, required exter-

\footnotetext{
${ }^{13}$ See Franks and Sussman (1999) for the historical background, and Scott and Smith (1986) for a comprehensive description of the reform.
} 
nal ..nance and, ultimately, the whole dynamic equilibrium described above. We model the structural change as follows. The enforcement mechanism used by ..nanciers is based on a 'threat' of liquidation which is imposed taking into account the possibility of renegotiation between the ..rm and the ..nanciers, prior to liquidation. Our model contains a parameter that describes the bargaining power of each party in these renegotiations. Hence, we model a reform of the type that took place in US bankruptcy law in 1978 as a change that increases the bargaining power of the ..rm vis-a-vis its ..nanciers. Table 2 presents the results.

\section{[insert Tabl e 2 about her e]}

Surprisingly enough, our model predicts that the reform will increase, rather than decrease, business fuctuations. The reason is that once the ..nancier understands that his bargaining position was curtailed, he also realizes that the exectiveness of his liquidation rights, in enforcing repayment, was diminished. To restore the viability of lending, ..nanciers will demand more liquidation rights. That will lead to more liquidations during the bust, accompanied by lower equipment prices. Lower equipment prices during the bust will favor contemporary start-ups and will rełect, among other things, in lower boom liquidation rates.

The empirical evidence in Leeth and Scott (1989) supports our prediction on lenders' reaction to the change in bankruptcy law. They examine the incidence of debt collateralization in a sample of small business loans, some of which were contracted before the date when the new law became exective (but after it was enacted) and some afterwards. The authors ...nd that $61 \%$ of the loans contracted after the new law became exective were collateralized and estimate that this number would have been smaller by 11 percentage points in the absence of the reform. This suggests that lenders increased collateralization in anticipation of the weaker ex-post bargaining power granted to them by the new law.

This result opens an avenue for further research. For the 1970's and 1980 's were a period of many structural changes, especially in the regulation of banking - c.f. Gilbert (1986), or B erger, K ashyap and Scalise (1995). The changes in structure generated changes in conduct: US ..rms became more 
highly levered (see Worthington, 1993, and our Figure 2) and junk-bond markets łourished (see Gertler and Lown, 1999). Others have suggested before that such changes might have important macroeconomic implications. For example, Sharpe (1994) presents some convincing evidence that high-levered ..rms respond more strongly to industry shocks than low-leverage ..rms. Our model provides a simple framework in which the general-equilibrium exects of such developments can be analyzed.

\section{Policy Implications}

In this section we examine the policy implications of our model. We assume that the government's objective is to smooth output łuctuations. We do not provide any rational for the desirability of such a policy goal. In other words, we do not discuss whether smoothing output can promote a more e\& cient allocation of resources. This question is handled more directly in Suarez and Sussman (1997) where a related endogenous-cycles model is analyzed. Since moral-hazard relations are economically wasteful, especially during the bust, one may anticipate that by smoothing the cycle long-term output may be increased. This is, indeed, the case. However, it is also the case that such policy bene.ts some agents while making others worse ox. In our case, smoothing the cycle may not be in the interest of bust start-ups, who buy capital goods at low prices, and face possible liquidation into a high-price market. In many cases, higher total resources may be reallocated so as to make everyone better ox. Unfortunately, such reallocation may not be possible in the presence of ..nancial imperfections.

The reason is the following. When capital markets are perfect, production decisions are taken on the basis of net-present-value considerations, regardless of how wealthy or liquid decision makers are. Obviously this is not true in our model, where projects may be liquidated just because of a temporary shortage of liquidity. The government may prevent some of these liquidations by subsidizing ..rms, reducing their need to be ..nanced externally. However, the government cannot tax these ..rms later on so as to cancel the wealth exect of the subsidy. Recall that the origin of the problems between ..rms and their ..nanciers is that no payments can be enforced towards the end of the 
..rm's life. Indeed, the same enforcement problems exist with taxation. J ust as the courts cannot enforce repayments of private loans, they cannot enforce government taxes. Hence, the government may avoid early liquidation by subsidies, but if it tries to tax these ..rms later on, it is on no better grounds to get paid than private lenders.

\subsection{Some policy steps}

For the rest of this section, we maintain the working hypothesis that the government aims at smoothing the business cycle. The ..rst policy we consider is of deepening of the second-hand market. Since our model operates via distressed sales of assets, a policy that relaxes the price-exect of such sales may prove stabilizing. Suppose the government can achieve such an exect by decreasing transaction costs or by treating second-hand trade more favorably, taxation wise. Suppose, also, that such a policy can be incorporated into our model by increasing the price-elasticity of new equipment. The exect on the business cycle is reported in Table 3. It is shown that during the bust when the demand for new equipment falls, prices do not fall that much (compared with Table 1); equally, during the boom, when the demand for new equipment increases, prices do not rise that much. Crucially, the exect on output is stabilizing: boom-bust amplitude falls from $7.5 \%$ in the benchmark case to $5.6 \%$ in the current case.

\section{[insert Tabl e 3 about her e]}

Alternatively, consider a policy of subsidizing the purchase of equipment by boom start-ups. Note that this policy is equivalent to lowering the lending rate during the boom (in reality by the end of the expansion period and towards the bust). The reason why the subsidy should be granted to boom start-ups is that they operate under tighter ..nancial conditions. The subsidy will decrease their reliance on external ..nance and allow the enforcement of more relaxed ..nancial contracts (i.e., lower-" contracts). As Table 4 shows, more relaxed ..nancial contracts during the boom imply a lower liquidation rate during the bust, so that equipment prices do not fall that much. Crucially, the exect on output is stabilizing as well. 
[insert Tabl e 4 about her e]

Lastly, consider a bail out policy. Suppose the government pays the debt of a small fraction of ..rms in default during a bust period. Interestingly, the exect of such policy is not clear in advance. On the one hand, some companies in distress will avoid liquidation. On the other hand, non-distressed ..rms will have an incentive to declare default so as to qualify for the subsidy. If that exect of the policy is foreseen in advance, lenders will tighten up ..nancial contracts (i.e., increase ${ }^{-}$) for boom start-ups. ${ }^{14}$ Our results show that the former exect dominates the latter, so the net liquidation rate during the bust falls (compare Table 5 with Table 1).

[insert Tabl e 5 about her e]

\subsection{Should policy accommodate?}

We showed above that the economy may be stabilized by allowing the supply of new equipment to respond more elastically to fuctuations in demand, by relaxing the price of funds during periods of high demand, and by bailing out some companies during recession. ${ }^{15}$ In terms of the old-fashioned macro literature a la Poole (1970), the three policies described above can be summarized in one word: accommodation.

This result is somewhat in contrast to the current trend in central banking: either lean against the wind or simply ignore the wind. It is important to stress, however, that the general conclusion here is not 'always accommodate' but rather 'accommodate to ..nancial ¥uctuations.' Other economic illnesses, most notably in $\ddagger$ ation, are not analyzed within the current framework. Most likely, the optimal response to some of these other problems is to lean against the wind.

Hence, historical experience and recent academic research seem to imply that policy makers should no longer neglect the macroeconomic exects of

\footnotetext{
${ }^{14} \mathrm{R}$ emember that we analyze the exect of the policy several cycles after its inception, when everyone is fully aware of its implications.

${ }^{15} \mathrm{~A}$ similar view is expressed by Allen and $\mathrm{G}$ ale (1999). N ote that our analysis imposes stronger restrictions on the policy makers, since we allow players to 'learn' (anticipate) the exect of the policy. Yet, the stabilizing exect is delivered.
} 
..nancial distress. Instead of ignoring the wind, policy makers will have to ask 'what sort of a wind' and then use discretion to decide whether to accommodate or lean against it. The behavior of central banks since the outbreak of the East Asian ...nancial crisis suggests that this sort of policy has already been put in action.

\subsection{A note on liberalization}

The reader may have noticed that the changes in parameter values used to generate the wide set of results described above were remarkably small. This rełects a general property of models with non-linear dynamics: tiny changes in structure may cause the system to respond violently. Moreover, the exects are very diф cult to predict, since extrapolations become easily very inaccurate.

This feature of the model captures nicely an observation that is often made: that many ..nancial disasters have followed episodes of ..nancial liberalization or some other structural change. In many cases, the size and scope of the structural change was modest: see Englund (1999) and Allen and Gale (1999). Ex post analysis of these processes often leave the impression that the severity of the consequences was impossible to predict. Accordingly, policy makers might be right when feeling that structural changes are always hazardous.

\section{Conclusions}

There is an old tradition in macroeconomics that considers business cycles as an endogenously generated and ..nancially driven phenomenon. This tradition was almost ignored for about ..fty years. We believe that this oblivion was unfortunate. Of course, the question whether the world is random or deterministic is more metaphysical than scienti..c. Yet, recent models of endogenous ..nancial business cycles are both intuitive and handy. They generate a rich set of plausible empirical predictions and some sensible policy implications. M ore importantly for researchers, they are interesting and have just started to be explored. We hope macroeconomists will ..nd them useful and will carry their development further ahead. 


\section{Appendix}

The tables that summarize our simulation results describe the behavior of some key macroeconomic variables along a stationary two-period cycle generated by our model under speci..c values of its parameters. One should think of a model period as covering about 5 calendar years. The parameters used in the simulations fall within ranges consistent with the existing empirical evidence on depreciation rates, default rates, capital-output ratios, and the price elasticity of the supply of capital goods in developed economies. In the benchmark simulation (Table 1), they are chosen to produce oscillations in output with an amplitude of $7.5 \%$ (percentage increase from the bust to the boom), which is about the amplitude of the HP cyclical component of US GDP. For further details, see Suarez and Sussman (1999).

The variables that appear in the tables are de..ned as follows:

2 Amplitude: For variables in levels, it is the percentage increase from the bust to the boom; for variables in percentage points, it is the dixerence between the value at the boom and the value at the bust.

2 Output includes the production of ..rms that are not discontinued and the value added in the production of equipment (equipment production - consumption good used as an input); equipment production is valued in terms of the consumption good using current relative prices.

2 Gross investment is equipment production valued in terms of the consumption good using current relative prices.

2 Liquidation measures the (annualized) probability with which a ..rm end ups liquidated as a consequence of ..nancial distress.

2 Price of equipment is the price of equipment in terms of the consumption good.

2 - is the probability of liquidation of ..rms that default as set in the contracts signed during the period of reference. 
2 Interest rate spread: Since in all simulations the riskless interest rate is assumed to be zero, the spread is computed as the (annualized) interest rate implied by the repayment that entrepreneurs promise to their ..nanciers in exchange for the funds initially borrowed from them. 


\section{R eferences}

Allen, Franklin and Douglas Gale (1998). "Bubbles and Crisis," Economic J ournal, forthcoming.

Allen, Franklin and Douglas Gale (1999). "Bubbles, Crises and Policy," Oxford Review of Economic Policy, this issue.

Altman, Edward I. (1983). "W hy Business Fail," J ournal of Business Strategy, 3(4) pp. 15-21.

Altman, Edward I. (1989)."The 'J unk Bond' Default Rate Debate," Leonard N. Stern School of Business WP 539, New York.

Bagehot, Walter (1873). Lombard Street: A Description of the Money Market, available at http:// socserv2.socsci.mcmaster.ca/ econ / ugcm/ 3113.

Berger, Allen N., A nil K. K ashyap, and J oseph M. Scalise (1995). "T he Transformation of the U.S. Banking Industry: What a Long, Strange Trip It's Been," B rookings Papers on Economic Activity, 0(2), pp. 55-201.

B ernanke, Ben, M ark Gertler, and Simon Gilchrist (1998). "T he F inancial Accelerator in a Quantitative Business-Cycle Framework," NBER WP 5455, forthcoming in Handbook of Macroeconomics.

Bolton, Patrick and David Scharfstein (1996). "Optimal Debt Structure and the Number of Creditors," J ournal of Political Economy, 104, pp. 1-25.

Englund, Peter (1999). "The Swedish Banking Crisis-R oots and Consequences," Oxford Review of Economic Policy, this issue.

Fisher, Irving (1933). "The Debt-D ełation Theory of Great Depressions," Econometrica, 1, pp. 337-357.

Franks, J ulian and Oren Sussman (1999). "Financial Innovations and Corporate Insolvency," mimeo, London Business School.

Franks, J ulian R and Walter N. Torous (1989). "An Empirical Investigation of U.S. Firms in Reorganization," J ournal of Finance, 44(3), pp. 747-69.

Gertler, Mark and Cara Lown (1999). "The Information in the in the High-yield B ond Spread for the Business Cycle: Evidence 
and Some Implications," Oxford Review of E conomic Policy, this issue.

Gilbert, Alton R. (1986). "R equiem for Regulation Q: What It Did and Why It Passed A way," Federal Reseve Bank of St. Luis, 68(2), pp. 22-38.

Gilson, Stuart C., K ose J ohn, and Larry H. P. Lang (1990). "Troubled Debt Restructurings: An Empirical Study of Private Reorganization of F irms in Default," J ournal of Financial E conomics, 27(2), pp. 315-53.

Hart, Oliver and J ohn H. Moore (1998). "Default and Renegotiation: A Dynamic Model of Debt," Quarterly J ournal of Economics, 113, pp. 1-41.

Higgins, Matthew and Carol Osler (1997). "A sset Market Hangovers and Economic Growth: The OECD during 1984-93," Oxford Review of Economic Policy, 13(3), pp. 110-34.

Mishkin, Frederic S. (1996). "Understanding Financial Crisis: A Developing Country Perspective," NBER WP 5600.

Morris, Stephen and Hyun Song Shin (1999). "Coordination Risk and the Price of Debt," mimeo, University of Oxford.

Leeth, J ohn D. and J onathan A. Scott (1989). "The Incidence of Secured Debt: Evidence from the Small Business Community," J ournal of Financial and Quantitative Analysis, 24(3), pp. 379394

Patinkin, Don (1989). Money, Interest, and Prices: An Integration of Monetary and Value Theory. Cambridge, Mass. and London: MIT Press.

Platt, Harlan D. and M arjorie B. Platt (1994). "B usiness Cycle Exects on State Corporate Failure Rates," J ournal of Economics and Business, 46, pp. 113-127.

Pulvino, Todd C. (1998). "Do Asset Fire Sales Exist? An Empirical Investigation of Commercial Aircraft Transactions," J ournal of Finance, 53, pp. 939-978.

Schumpeter, J oseph A. (1996). The Theory of Economic Development, New Brunswick: Transaction Publishers. (First published 
in 1911, ..rst translation into English in 1934).

Scott, J onathan A . and Terence C. Smith (1986). "The Exect of Bankruptcy Reform Act of 1978 on Small Business Loan Pricing," J ournal of Financial Economics, 16, pp. 119-140.

Sharpe, Steven (1994). "F inancial Market Imperfection, Firm Leverage, and the Cyclicality of Employment," American Economic Review, 84, pp. 1060-1074.

Shleifer, Andrei and Robert Vishny (1992). "Liquidation Values and Debt Capacity: A Market Equilibrium A pproach," J ournal of Finance, 47, pp. 1343-1365.

Suarez, Javier and Oren Sussman (1997). "Endogenous Cycles in a Stiglitz-Weiss Economy," J ournal of Economic Theory, 76, pp. 47-71.

Suarez, J avier and Oren Sussman (1999). "A Stylized M odel of FinanciallyDriven Business Cycles," mimeo, CEMFI, Madrid.

Worthington, Paula R. (1993). "Recent Trends in Corporate Leverage," Federal Reserve Bank of Chicago Economic Perspectives, 17(3), pp. 24-31. 


\section{Table 1: The Benchmark Simulation}

This table presents a benchmark for the other simulations in the paper. For more details about the model's parameter values and the de..nitions of variables, see the A ppendix.

\begin{tabular}{lccc}
\hline & Bust & B oom & A mplitude \\
\hline Output & 2.65 & 2.85 & 7.5 \\
Gross investment & 0.37 & 0.45 & 21.6 \\
Liquidation (\%) & 4.5 & 3.7 & -0.8 \\
Price of equipment & 0.42 & 0.50 & 18.7 \\
- (\%) & 61.3 & 75.6 & 14.3 \\
Interest rate spread (\%) & 4.9 & 5.3 & 0.4 \\
\hline
\end{tabular}




\section{Table 2: The Exect of Corporate Bankruptcy Reform}

In this table we examine the exect of a legal reform that shifts power away from the ..nancier to the ..rm. Technically, the parameter, which measures the .rms share of bargaining power is increased from 0.5 , in Table 1, to 0.501 , in this table. All other parameters stay the same.

\begin{tabular}{lccc}
\hline & Bust & B oom & Amplitude \\
\hline Output & 2.59 & 2.90 & 12.0 \\
Gross investment & 0.35 & 0.48 & 35.6 \\
Liquidation (\%) & 4.8 & 3.5 & -1.3 \\
Price of equipment & 0.40 & 0.52 & 30.7 \\
- (\%) & 57.6 & 79.9 & 22.3 \\
Interest rate spread (\%) & 4.8 & 5.3 & 0.5 \\
\hline
\end{tabular}


Table 3: The Exect of Deepening the Second-Hand M arket

In this table we examine the exect of deepening the second-hand market. That is done by increasing the price-elasticity of the supply schedule of capital goods. Technically the elasticity parameter \# is increased from 0.1392, in Table 1, to 0.1393 , in this table. All other parameters stay the same.

\begin{tabular}{lccc}
\hline & Bust & Boom & A mplitude \\
\hline Output & 2.67 & 2.82 & 5.6 \\
Gross investment & 0.38 & 0.44 & 15.9 \\
Liquidation (\%) & 4.4 & 3.8 & -0.6 \\
Price of equipment & 0.43 & 0.49 & 13.8 \\
- (\%) & 63.0 & 73.8 & 10.8 \\
Interest rate spread (\%) & 5.0 & 5.2 & 0.2 \\
\hline
\end{tabular}


Table 4: The Exect of Subsidizing Start-ups in the Boom

In this table we examine the exect of a subsidy on the purchase of equipment by boom start-ups (i.e., those that operate under tighter ..nancial conditions). Technically, we assume that a fraction $\mathrm{s}$ of their investment is paid by the government. The value of $S$ is increased from its implicit value of zero in Table 1 to 0.0004 in this table. All other parameters stay the same.

\begin{tabular}{lccc}
\hline & Bust & Boom & A mplitude \\
\hline Output & 2.66 & 2.83 & 6.4 \\
Gross investment & 0.38 & 0.45 & 18.2 \\
Liquidation (\%) & 4.5 & 3.7 & -0.7 \\
Price of equipment & 0.43 & 0.49 & 15.8 \\
- (\%) & 62.3 & 74.5 & 12.2 \\
Interest rate spread (\%) & 4.9 & 5.2 & 0.3 \\
\hline
\end{tabular}




\section{Table 5: The Exect of Bail-Outs in the Bust}

In this table we examine the exect of a policy consisting in bailing out some of the ..rms that go bankrupt during bust periods. Technically, we assume that the government repays the debt of $a$ fraction $b$ of the ..rms in default that would otherwise be liquidated. The value of $b$ is increased from its implicit value of zero in Table 1 to 0.001 in this table. All other parameters stay the same.

\begin{tabular}{lccc}
\hline & Bust & Boom & A mplitude \\
\hline Output & 2.66 & 2.83 & 6.4 \\
Gross investment & 0.38 & 0.45 & 18.3 \\
Liquidation (\%) & 4.5 & 3.7 & -0.7 \\
Price of equipment & 0.43 & 0.49 & 15.9 \\
- (\%) & 62.2 & 74.5 & 12.3 \\
Interest rate spread (\%) & 4.9 & 5.2 & 0.3 \\
\hline
\end{tabular}




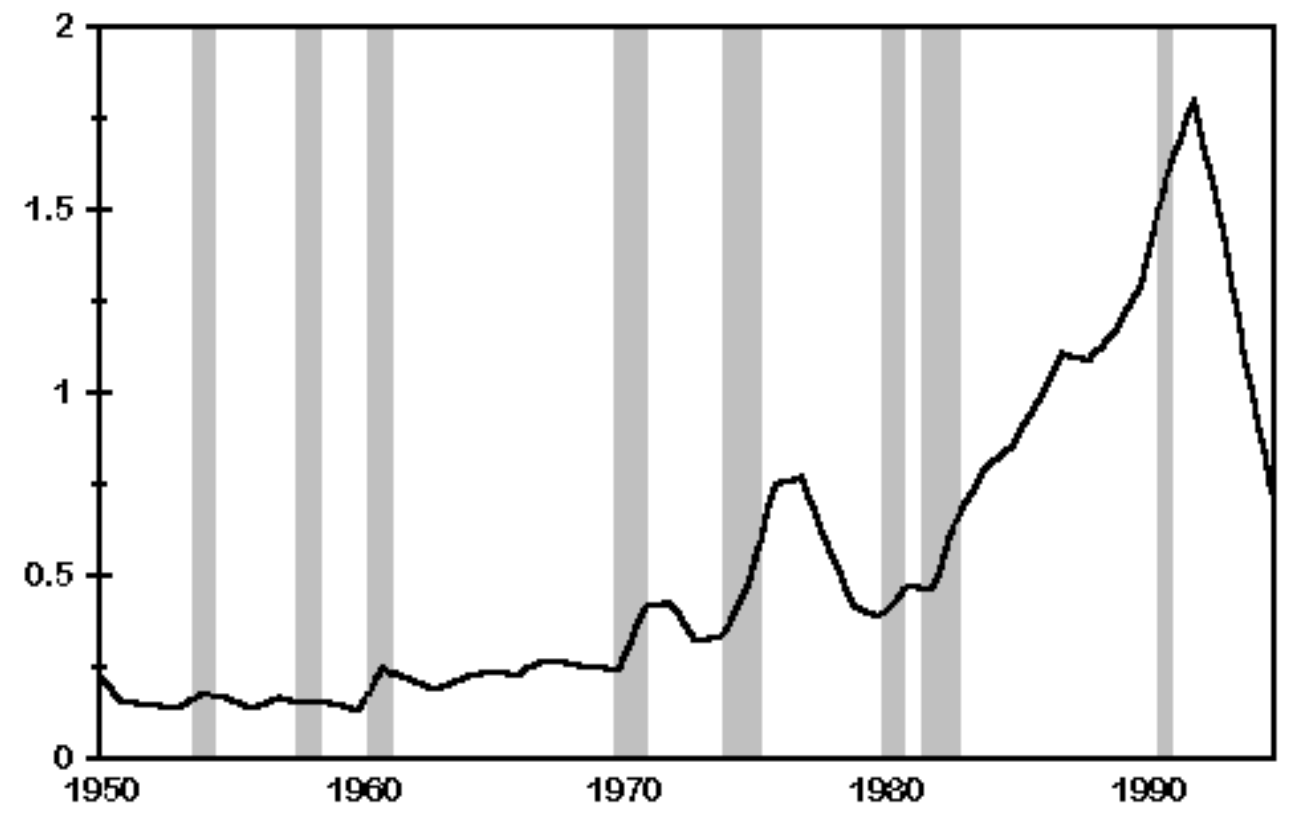

Figure 1: Financial Distress

This ..gure represents the evolution of ..nancial distress in the US during the postwar period. We use the percentage ratio of banks' Gross Charge-oxs to their Gross Loans and Lease as reported in the Historical Statistics of the Federal Deposit Insurance Corporation (FDIC). The shading indicates NBER recessions. 


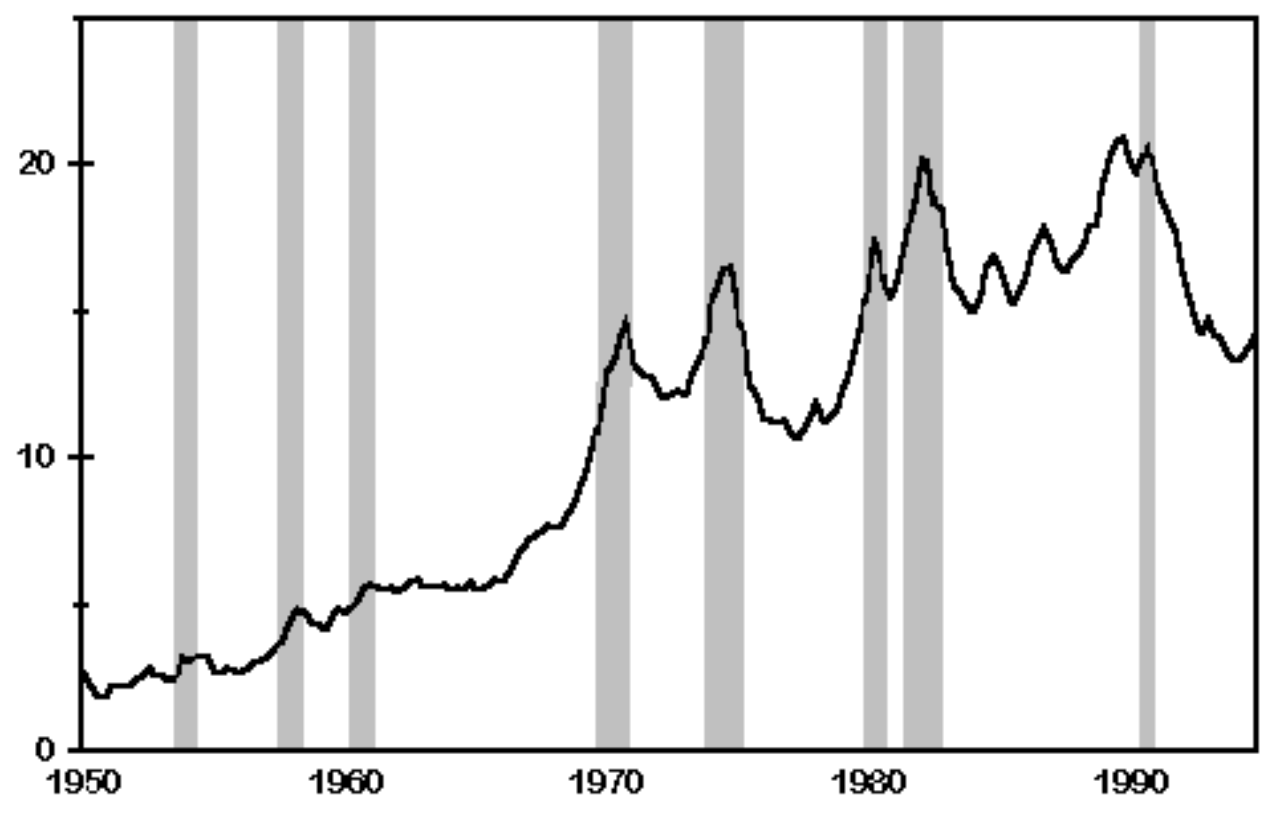

Figure 2: Leverage

This ..gure represents the evolution of leverage in the US Non-..nancial Corporate B usiness sector during the post-war period. We use the percentage ratio of Interest Payments to Pre-tax Capital Income for the as reported by the National Income and Product Accounts (NIPA). The shading indicates NBER recessions. 